\title{
Offshoring IT Services: Influencing Factors
}

\author{
Vipin K. Agrawal \\ University of Texas at San Antonio \\ Vijay K. Agrawal \\ University of Nebraska at Kearney \\ A. Ross Taylor \\ University of Nebraska at Kearney \\ Srivatsa Seshadri \\ University of Nebraska at Kearney
}

A growing number of American companies have embraced offshore outsourcing (offshoring) of services. More recently, offshoring has expanded to include more sophisticated and advanced activities like research, design, engineering, and product development. Few empirical studies have been conducted on the forces driving offshoring in the Information Technology (IT) sector. The theoretical frameworks explaining the increase in globalization have often neglected the service sector - now accounting for a significant proportion of global trade volume. In this study, the authors partially address this gap by investigating factors that influence offshoring decisions made by IT managers in the United States.

Keywords: Offshoring IT, Factors enabling/inhibiting, IT Outsourcing Growth

\section{INTRODUCTION}

The powerful forces of globalization during the past few decades changed the rules of competition in business (Gottfredson, Puryear, and Phillips, 2005; Hilletofth and Jäger, 2011), contributing to the offshoring trend. The intense pressures on firms to not only survive but continue to deliver profits to investors in the face of such globalization has grown incessantly (Baden-Fuller, Targett, and Hunt, 2000; Hilletofth and Hilmola, 2010). To meet this pressure many firms embraced offshore outsourcing, made even more attractive due to the economic liberalization in China and India, which opened up low cost supply chains. Additionally, the access to new resources such as an abundant supply of human resources talent provided a further boost to offshoring (Holcomb and Hitt, 2007).

In this environment of global competition, firms are compelled to focus on activities they have the core competencies in and to outsource the other activities. Offshoring less significant activities to those that specialize in those activities enables a firm to generate more value by focusing on its core activities 
(Letica 2016). Until just before the beginning of the 21st century, firms that engaged in offshoring were largely limited to the manufacturing sector. The past two decades has however seen a significant growth of offshoring in the service industry, particularly in the Information Technology (IT) sector. In this regard, the IT sector appears to show some parallels to the manufacturing sector in that the liberalization of trade and the dramatic drop in transportation, data transmission and tariff costs (Contractor, Kumar, Kundu, and Pedersen 2010), and powered by product complexities and technological innovations (Kang, Wu, Hong, and Park, 2012), appear to drive offshoring decisions.

\section{IT Offshoring}

IT offshoring refers to the practice of shifting one or more organizational IT-related activities to an outside firm abroad (Schwarz, 2014). According to Venkatraman (2004), offshoring is the practice of migrating business processes overseas (business process offshoring) in order to lower costs without significantly sacrificing quality. Kern and Willcocks (2002) define IT offshoring as "a process whereby an organization decides to contract-out or sell the firm's IT assets, people and/or activities to a third-party supplier abroad, who, in exchange, provides and manages these assets and services for an agreed fee over an agreed time period." As global supply markets have continued to expand, businesses now have the opportunity to reassess which IT functions should remain in-house and which could be outsourced (Marchewka and Oruganti, 2013).

While management and accounting scholars have lauded offshoring as a promising business strategy since the 1990s (e.g., Bardi and Tracey 1991; Sonnenberg 1992; Apte and Mason 1995; Lei and Hitt 1995; Anderson and Sedatole 2003), offshoring of IT is a relatively recent trend (IAOP 2010). Offshoring of IT has become more prevalent due to technological advancements that have significantly improved the extent, speed, and reliability of global communications, decreased communication costs, and facilitated management of offshoring contracts (Levy 2005; Blinder 2006; Stratman 2008; Contractor, Kumar, Kundu, and Pedersen 2010). As a result, it has become a common business practice rather than a rare exception (Iyengar 2011; Reynolds 2012; Fitoussi and Gurbaxani 2012; Han and Mithas 2013).

Research by Gartner predicts that small-to-medium-size companies' expenditure on IT will grow annually by 3.9 percent (Jain and Khurana 2015). The worldwide (U.S.) market of IT offshoring is predicted to have a five-year compound annual growth rate of 5.7 percent (4.3 percent); it reached $\$ 209.4$ (\$97.3) billion in 2017 (IDC 2013). The percentage of IT offshoring of entire IT spending has varied by industry. For example: government from $17 \%$ to $25 \%$, communications $25 \%$, banking $18 \%$, commerce $18 \%$, materials and resource industries $16 \%$, education $8 \%$ (Kriger et al. 2016). However, although the IT offshoring phenomenon has been expanding during the last decade, the success rate remains low (Kim, Lee, Koo, and Nam, 2013). Despite the ever-growing trend towards outsourcing, few organizations openly declare to have achieved success with offshoring (Huber, Fisher, Kirsch, and Dibbern, 2014).

Industry and academic research studies (e.g. Gottfredson, Puryear, and Phillips, 2005) have noted that the advances in IT have rendered business capabilities globally portable; for example, Westner and Strahringer (2010a) found among large German corporations that more than half of them had outsourced functions to India. The promise of strategic, financial and technological benefits motivates offshoring decisions (Lee and Kim 1999). During the 2000s offshoring became an accepted mainstream business practice, and, according to Offshore Research Network, the most frequently offshored business function was IT (Manning Massini, and Lewin. 2008). Offshoring not only resulted in cost reductions, but it also aligned well with a company's growth strategies, addressed competitive pressures, and provided access to qualified personnel (Lewin and Peeters, 2006). Offshoring has matured from a purely cost-saving tool to a powerful strategy for business transformation (Linder 2004a).

\section{IT Backsourcing}

Veltri, Saunders, and Kavan (2008) argue that an increasing number of companies are taking IT functions back into the organization, known as backsourcing (also known as insourcing) because of the negative experiences of offshoring. Backsourcing is defined as "the process of recalling operations back in-house after they have been outsourced" (Bhagwatwar, Hackey, and Desouza, 2011; Solli-Sæther and 
Gottschalk, 2015). Firms such as Continental Airlines, Farmers Group, Washington Mutual, Xerox (Veltri, Saunders, and Kavan, 2008), and JP Morgan Chase (Bhagwatwar, Hackey, and Desouza 2011, Overby 2005) backsourced several of their activities. A research study by Whitten and Leidner (2006) found that $34 \%$ of the firms surveyed in the US and Canada had backsourced. A combination of excessive coordination costs (Jorgensen 2013), poor service, loss of control, know-how mismatch, as well as appointments of new executives, IS role changes, and external business changes (Veltri, Saunders, and Kavan , 2008) seem to have an impetus to backsource activities that were offshored.

However, the trend towards the offshoring of IT processes has kept increasing throughout the world's developed economies during the last few years (Kim, Lee, Koo, and Nam, 2013). The truth is that IT offshoring has come to stay. The percentage of total IT budget spent on IT offshoring rose from $10.6 \%$ in 2016 to $11.9 \%$ in 2017 with the percentage hovering between $10.2 \%$ and $10.6 \%$ for the previous four years Computer Economics (2017c). Some IT activities, such as application development, are being outsourced entirely or partly by 61 per cent of organizations (Computer Economics 2017b).

The report, "IT Key Metrics Data", published every year since 1996 are based on research from Gartner Company (Gartner Consulting 2014). These documents include primary data collected directly from IT employees of companies (chief information officers (CIO), managers, and IT leaders), and special marketing research. IT Outsource Spending as a percent of IT spending averages 18\%. Some companies use it more than $90 \%$. The percentage of IT offshoring of entire IT spending varies by industry. For example: government from $17 \%$ to $25 \%$, communications $25 \%$, banking $18 \%$, commerce $18 \%$, materials and resource industries $16 \%$, education $8 \%$ (Kriger et al. 2016).

\section{LITERATURE REVIEW}

Information technology offshoring (ITO) has experienced tremendous growth the past 20 years and has aroused great enthusiasm among academic researchers (Lacity, Khan, and Willcocks 2009). Though economic literature has established that comparative advantages determine the appeal of locations to host economic activities, the incidences of backsourcing give pause to the advantages of offshoring. The savings in labor-costs appears to be counterbalanced by the related coordination and transportation costs. In offshoring IT activities the negative influence on costs of transportation are minimal, but the higher coordination costs oblige firms to evaluate the risk-benefit ratios. The intense globally competitive environment has required firms to pursue complex offshoring goals that include efficiency, flexibility, innovativeness and sustainability (Kang et al, 2012).

\section{Benefits of Offshoring Solutions}

Although traditional approaches to offshoring were designed to ensure economies of scale and gain efficiency (Lacity, Willcocks, and Feeney 1995), companies also hoped that their offshoring partners would introduce innovative technologies and associated services (Levina and Su 2008) and some leading companies are reinventing their supplier portfolio to achieve that goal ( $\mathrm{Su}$, Levina, and Ross. 2016). Toyota Motor North America Inc. has outsourced $80 \%$ of its IT workforce, which has enabled the company to cut information-systems support costs (Betancourt, Mooney and Ross 2015).

According to the resource-based theory, every single company is a unique bundle of assets and resources that if employed in distinctive ways can create competitive advantage (Barney, 1991, 2012). For a firm, as an effect of globalization, the location of the suppliers and the identification of the most favorable opportunities for inputs must take place on a global scale to maintain and grow its market position (Gereffi and Lee 2012). Several authors has identified the many benefits of offshoring. These include cost savings (Choi and Beladi 2014, Luftman et al. 2013, Zhu 2016), quality improvement (Bustinza, Arias-Aranda, and Gutierrez-Gutierrez 2010, Holweg, Reichhart, and Hong 2011), new innovations in product or process (Bakhtiari 2015, Nassimbeni 2006), access to input resources (Holweg, Reichhart, and Hong 2011, Nassimbeni 2006, Zeng and Rossetti 2003), access to new markets (Nieto and Rodriguez 2011, Rodriguez and Nieto 2016), speeding up time-to-Market (McNally, Akdeniz, and 
Calantone, 2011, Zhu 2016), and access to new technologies (Jain and Khurana 2013, Li, Liu, Li, \& Wu 2008; Prikladnicki and Audy 2012).

A key economic benefit of offshoring mentioned prominently by both sellers and buyers of this practice is that it allows the offshoring firm to reduce its fixed cost and convert it into variable cost (Bustinza, Arias-Aranda, and Gutierrez-Gutierrez 2010, Dabhilkar, Bengtsson, von Haartman, and Ahlstrom 2009, Kremic, Tukel, \& Rom, 2006; Seddon, Cullen, and Willcocks 2007). Specifically, the offshoring firm can avoid a significant part of the fixed costs of facilities, equipment, information technology, rents, personnel salary, insurance, and logistic and overhead expenses. Thus the organizations achieve greater financial flexibility by selling assets that were formerly used in the outsourced activities in order to improve a company's cash flow (Dolgui and Proth 2013). Furthermore, the vendor can offer a creative and structured lease, which may allow the company to partly or fully initiate, finance, and staff its strategic new initiatives at relatively low risk. The company thus can transfer the risk of failure largely to the vendor, especially in the areas where the company does not have core competence (Dhar 2012). Further, while companies may be loath to acknowledge it, the persistent threat that jobs may be offshored stimulates productivity among domestic workers (Business News Daily, 2010).

Thus, offshoring can be an effective strategy to compete globally (Di Gregorio, Musteen, \& Thomas 2009; Li, Liu, Li, \& Wu 2008).

\section{Risks in Offshoring Solution}

Though the potential for capturing and increasing value in the value-chain is significant, it is not without risks. A managerial survey by the offshoring Center (Goolsby 2004) found that poor governance choice, lack of information sharing, and misalignment of client and vendor interest caused by volatility in the client's business environment or changes to task requirements account for 39 percent of offshoring failure.

Offshoring has not generated the expected returns for some firms, as testified by executives who have experienced the harsh realities of offshoring (Aron and Singh 2005). The costs inherent in the complexity of coordination due to the environmental dynamism - the volatility, unpredictability, and uncertainty of environments - of dispersed locations offshore, and the lack of flexibility among offshore service providers resulted in a worst performance for some ( $\mathrm{Li}$ and Scullion 2006, Tadelis 2007, Tsao and Chen 2012). A 2012 survey on IT offshoring showed that approximately one-third of outsourced IT projects produced an ineffectual or negative outcome (Lacity \& Willcocks, 2012). More than $50 \%$ of outsourced IT projects were terminated before the contract expired and switched to other vendors or in-house development (Qi \& Chau, 2012 ; Whitten \& Leidner, 2006). An additional 23 percent of failures were attributed to unclear buyer expectations, which could be broadly attributed to poor communication and inappropriate governance structure.

The many potential risks associated with offshoring include: becoming dependent on outside suppliers for services (Kakabadse and Kakabadse 2000, Horgos 2009), hidden costs of offshoring (Bahli \& Rivard 2013, Platts and Song 2010), losing control over critical functions (Prikladnicki and Audy 2012, Wüllenweber and Weitzel 2007), relationships going wrong (Kakabadse and Kakabadse 2000, Horgos 2009, Platts and Song 2010), lowering the morale of permanent employees because of reduction in staff (Dolgui and Proth 2013, Platts and Song 2010), protection of intellectual property (Ranganathan and Balaji 2007, Rottman and Lacity 2004), data insecurity (Carmel 2006, Oshri, Kotlarsky, and Willcocks 2007), privacy protection problems (Carmel 2006, Oshri, Kotlarsky, and Willcocks 2007, Ranganathan and Balaji 2007, Rottman and Lacity 2004), knowledge protection issues (Wüllenweber and Weitzel 2007), difficulties in IT management (Choudhury \& Sabherwal, 2003, Natovich, 2003 ), loss of critical skills, developing the wrong skills, the loss of cross-functional skills (Gaudenzi and Borghesi 2006, Olson and $\mathrm{Wu}$ 2011, Rao and Goldsby 2009, Tafti 2005), and the loss of control over vendors/suppliers (Olson and $\mathrm{Wu}$ 2011, Rao and Goldsby 2009, Gaudenzi and Borghesi 2006).

Then there are the offshoring challenges of having to manage the differences in language, culture, and time zones, with different laws and regulations in the offshored country (Carmel 2006, Oshri, Kotlarsky, and Willcocks 2007, Ranganathan and Balaji 2007, Rottman and Lacity 2004), dealing with poor 
infrastructure (telecommunication and electric supply) at offshore vendor's site (Carmel 2003), deficient quality management due to lack of training, lack of managerial skills, as well as insufficient project management and implementation skills among some offshore providers (Zatolyuk and Allgood 2004).

The firm offshoring IT operations also has to deal with domestic blowbacks due to the resulting unemployment is the country (Dolgui and Proth 2013). Recent economic pressures have led governments in the United States and Europe to 'encourage' multinationals to return jobs and investment back to home markets (BCG 2013).

The greater financial flexibility in offshoring through the sale of assets can have a negative impact on future development within the offshoring firm because they will be fully dependent (lock-in effect) on the vendor (Dolgui and Proth 2013, Earl 1996). Earl (1996) stated lack of innovation as a significant risk of offshoring IT activities.

\section{Bandwagon Effect}

The bandwagon effect is an occurrence when one chooses an option because others have. The bandwagon effect results from the perceived pressure felt by managers from prior adopters of a technology or a business process in the extant environment (Hess 2018). According to Bianchi, Di Benedetto, Franzo, and Frattini (2017) the perceived pressure from the bandwagon effect has two origins: Information contagion and fad theory. Managers fear losing competitive advantages gained by offshoring to early adopters and are therefore motivated to adopt the offshoring strategy. Synonymous with 'herd behavior' the bandwagon effect encourages managers to follow the herd, impelled by desire to benefit from whatever others are benefitting from. The herd mentality will drive managers to embrace offshoring, ignoring the associated risks. Diffusion theory (Rogers 2010) also suggests that relative advantages and observability of benefits accrued by early adopters of offshoring provide the impetus for managers to adopt similar these strategies. It is therefore highly likely that the perceived benefits of offshoring will overpower the any perceived risks.

\section{H1: Expected Growth in offshoring is more influenced by perceived benefits than by perceived risks}

\section{Risk Aversion}

Efficient management of risk has long been recognized as an important determinant of firm performance. Risk aversion is generally assumed in decisions made under uncertainty (Tversky and Kahneman 1992). It is to be expected that in decisions regarding offshoring, where managers' knowledge of the vendors and their business cultures is likely low and uncertain, the fear of loss triumphs over the hope of benefits. In offshoring, the additional uncertainty of currency fluctuations hinders the perceptions of benefits. Fear of unknown losses loom larger than potential gains (Tversky and Kahneman 1984). Higher levels of risk aversion - and attendant fears of loss - may make managers less open to offshoring. Therefore, loss aversion is more likely sway their decision to offshore jobs.

\section{H2: Expected Growth in offshoring is more influenced by perceived risks than by perceived benefits}

\section{Administrative Motivation of Offshoring Solutions}

Research on offshoring suggests that firms are also driven to move business activities across national borders by a force external to the firm - the shortage of talent domestically (Hahn, Bunyaratavej, and Doh 2011, Manning, Massini, and Lewin. 2008, Massini, Perm-Ajchariyawong, and Lewin 2010). A study by KPMG in 2014/15 indicates that the reasons for planning offshoring will include access to skills (Lewin and Peeters, 2006).

A large stream of literature using agency theory (Deutsch, Keil, \& Laamanen, 2011) points out that managers cannot easily diversify their human capital. Therefore, one solution to this constraint is to offshore tasks. Agency theory posits that managers are motivated to embrace offshoring as a means of geographic diversification (Peng and Delios 2006), enhance the scale of operations through offshoring (Gomez-Mejia and Palich 1997) and thus potentially cement their competitive position by enhancing their 
managerial skills. Therefore, the administrative motivations will likely be a leading factor in the decision by managers to offshore IT activities.

\section{H3: Administrative motivation has a significant positive impact on expected growth in offshoring}

\section{Desired Characteristics of Offshoring Solutions}

The future competitive edge is seen to lie in flexibility that can be achieved through tight operational/core business focus and leveraging external core competences outside this focus area (e.g. Quinn 2000, Zhu, Hsu, and Lillie 2001). The ability to continuously restructure its value-chain becomes essential to maintain the competitive edge (Kakabadse and Kakabadse, 2002). The rapidly changing environment in IT across most industries calls for flexibility of business processes and adaptability of technologies with the existing pool of knowledge, skills and resources. Therefore, the new challenge lies in creating a flexible organization, in which a company focuses on selected key value creating competences and let globally dispersed outside experts provide the rest of the value by offshoring other activities.

Offshoring has been shown to provide greater flexibility (Farrell, 2005, Khan, Currie, Weerakkody, and Desai 2003, Pfannenstein and Tsai 2004) as well as to speed up responsiveness to the changes in demand (Bustinza, Arias-Aranda, and Gutierrez-Gutierrez 2010, Dabhilkar, Bengtsson, von Haartman, and Ahlstrom 2009). Yap, Lim and Lee (2013) asserted that firms, which could access expertise/skills, focus on core competency, and obtain flexibility through offshoring have a positive relation with IT offshoring. Offshoring to select vendors also confers the benefits such as flexibility and local responsiveness through the mechanism of decentralization (Teece 2007).

Outsourcing is often a by-product of another powerful management tool - business process reengineering. It allows an organization to immediately realize the anticipated benefits of accelerated reengineering by having an outside organization - one that is already reengineered to world-class standards - take over the process (Antonucci and Tucker 2013).

Hypothesis H4: The desired characteristics of IT offshoring has a significant positive impact on the expected growth in offshoring.

The four hypotheses are pictorially depicted in Figure 1. 


\section{FIGURE 1 \\ INFLUENCING FACTORS ON GROWTH IN IT OFFSHORING}

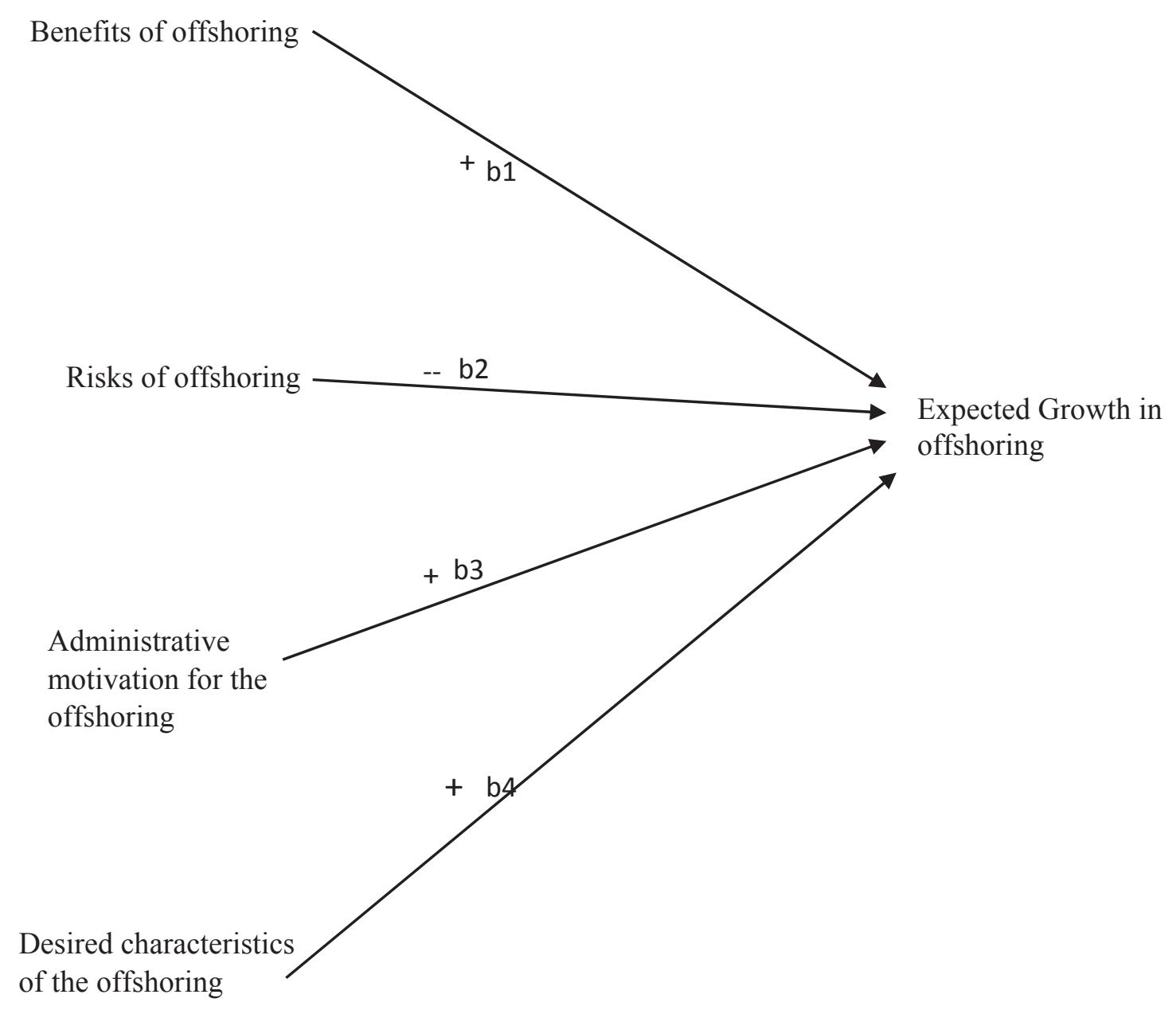

\section{METHODOLOGY}

A questionnaire survey was implemented to test the four hypotheses. The sample comprised of executives from manufacturing and service sectors in the United States. Based on the literature review a 6-page questionnaire was developed to measure variables of interest. The questionnaire items were finalized after assessing the items for face validity. To mitigate non-responses no open-ended questions were utilized.

Face-validity of each item was assessed in three steps. First, a list of items were initially developed for the questionnaire by the authors with expertise in the Management, MIS and IT disciplines. These items operationalized the variables of interest. A preliminary consensus was reached among them on the question-phrasings that evoked acceptable face-validity. Then, independently, each judge again assessed the face validity of each item. Each judge's assessments were then compared with each other for interrater concordance and the questions rephrased as required. Finally, four IT executives from different firms were asked to comment on the question phrasing and the time required to respond. Based on the feedbacks from them, and using a Delphi-like technique, the phrasing of the questions measuring the variables settled and finalized when all seven experts agreed that face-validity was for all items were achieved. Additionally, after data collection, a principal component factor analysis with Varimax rotation was conducted to verify that the four constructs ---- "Benefits of Offshoring," "Risks of Offshoring," 
"Administrative Motivation for the Offshoring," and "Desired Characteristics of Offshoring" --- were extracted. The variables measuring these constructs are shown in Table 1.

TABLE 1

ITEMS MEASURING CONSTRUCTS OF INTEREST

\begin{tabular}{|c|c|c|c|}
\hline Item & Factors & Items & $\begin{array}{l}\text { Cronbach's } \\
\text { Alpha }\end{array}$ \\
\hline 5 & \multirow{9}{*}{ Benefits of Offshoring (Rbenefit) } & $\begin{array}{l}\text { Financial risks shared with outsourced } \\
\text { vendor }\end{array}$ & \multirow{9}{*}{.941} \\
\hline 10 & & Increased availability of capital fund & \\
\hline 11 & & $\begin{array}{l}\text { Cash infusion from sale of assets to } \\
\text { outsourcers }\end{array}$ & \\
\hline 15 & & To improve customer satisfaction & \\
\hline 22 & & $\begin{array}{l}\text { Faster deployment cycle for software/quick } \\
\text { time to market }\end{array}$ & \\
\hline 23 & & Global scale & \\
\hline 24 & & 24 hours support and availability & \\
\hline 25 & & Improve quality of service & \\
\hline 28 & & Rapid change in business process cycle & \\
\hline 17 & \multirow{3}{*}{ Risk of Offshoring (Rrisk) } & $\begin{array}{l}\text { Higher resistance from employees - lower } \\
\text { employee morale, potential for poor quality }\end{array}$ & \multirow{3}{*}{.897} \\
\hline 19 & & Relationship management with supplier & \\
\hline 20 & & Risks during transition & \\
\hline 26 & \multirow{3}{*}{$\begin{array}{l}\text { Administrative Motivation for the } \\
\text { Offshoring (RAdminMotv) }\end{array}$} & Lack of experience in-house & \multirow{3}{*}{.845} \\
\hline 27 & & $\begin{array}{l}\text { Offered services we otherwise could not } \\
\text { subscribe }\end{array}$ & \\
\hline 29 & & Shrinkage in systems life cycle & \\
\hline 7 & \multirow{3}{*}{$\begin{array}{l}\text { Desired Characteristics of } \\
\text { Offshoring (RDesChar) }\end{array}$} & $\begin{array}{l}\text { Allows firms to be more flexible, dynamic, } \\
\text { and adaptable }\end{array}$ & \multirow{3}{*}{.854} \\
\hline 8 & & Redirection of resources & \\
\hline 9 & & Increased control of operating costs & \\
\hline
\end{tabular}

The subjects were also asked their Expected Growth in Offshoring (DeltaOut) in their firm, in the next five years, as a percentage. This variable was employed as the dependent variable in the statistical analysis of the four hypotheses.

\section{Data Collection}

Following the guidelines suggested by Dillman $(1978,2000)$, the questionnaire was administered. The targeted sample was IT professionals with some responsibility for making IT management decisions for organizations based in the United States. The sampling frame was a fee-based online panel of IT professionals offered by Qualtrics, a leading online survey research platform. Blankenship, Breen, and Dutka (1998) indicated that such online panels were of lower cost, provided faster responses, and had the ability to obtain a targeted sample of people who are scarce in the general population.

The questionnaire survey was sent to a panel of senior managerial IT professionals (directors, chief information officers, IT managers, etc.) of firms in the United States. Those who chose to participate were first asked to indicate the industry they were employed in. To ensure adequate representation of each industry type, target quotas of 80 service sector responses and 70 manufacturing sector responses were established. The service sector industry type had an additional target quota of 40 respondents in the 
Computer Software industry sector and 40 respondents for other service industry sectors. Once a quota was reached, Qualtrics deactivated the links given in the invitation to participate for that particular sector. The deactivated links were based upon the industry each respondent's panel profile indicated they were employed in. Respondents who began a survey before the link was deactivated were allowed to finish the survey. Out of the initial sample size of 153, the total of 148 usable responses were received, resulting in a $97 \%$ response rate.

\section{RESULTS}

Scores for the four factors - Benefits of Offshoring (Rbenefit), Risk of Offshoring (Rrisk), Administrative Motivation for the Offshoring (RAdminMotv), and Desired Characteristics of Offshoring (RDesChar) - and the dependent variable, Epected Growth in Offshoring, were first computed using SPSS Version 23.0. The hypotheses were tested

The testing of the hypotheses proceeded in two stages. In the first stage a correlation analysis was conducted to identify the hypotheses that could be rejected off-the-bat. Then a stepwise-regression was conducted to test the remaining hypotheses.

Scores for the four factors - Benefits of Offshoring (Rbenefit), Risk of Offshoring (Rrisk), Administrative Motivation for the Offshoring (RAdminMotv), and Desired Characteristics of Offshoring (RDesChar) - were first computed using SPSS Version 23.0. The hypotheses were tested using the stepwise-regression.

\section{First Step-wise Regression Results}

Table 2 shows the results of the first step-wise regression analysis. The analysis indicates that Administrative Motivation for the Offshoring (RAdminMotv) [ $b=-0.014, p=0.987]$, and Desired Characteristics of Offshoring (RDesChar) $[\mathrm{b}=-0.286, \mathrm{p}=0.744]$, do not play a significant role in influencing offshoring decisions.

Therefore, Hypothesis 3 and 4 were not supported.

TABLE 2

FIRST STEP-WISE REGRESSION ANALYSIS

\begin{tabular}{|l|r|r|r|r|r|}
\hline $\begin{array}{l}\text { Mode } \\
1\end{array}$ & $\mathrm{R}$ & Rodel Summary & \multicolumn{1}{c|}{$\begin{array}{c}\text { Adjusted R } \\
\text { Square }\end{array}$} & $\begin{array}{c}\text { Std. Error of the } \\
\text { Estimate }\end{array}$ & Durbin-Watson \\
\hline 1 & $.212^{\mathrm{a}}$ & .045 & .018 & 8.673 & 2.059 \\
\hline
\end{tabular}

a. Predictors: (Constant), RDesChar, RAdmnMotv, Rrisk, Rbenefit

b. Dependent Variable: DeltaOut

\begin{tabular}{|c|c|c|c|c|c|c|}
\hline \multicolumn{7}{|c|}{ ANOVA $^{\mathrm{a}}$} \\
\hline & & Sum of Squares & df & Mean Square & $\mathrm{F}$ & Sig. \\
\hline & Regression & 505.273 & 4 & 126.318 & 1.679 & $.158^{\mathrm{b}}$ \\
\hline & Residual & 10756.159 & 143 & 75.218 & & \\
\hline & Total & 11261.432 & 147 & & & \\
\hline
\end{tabular}

a. Dependent Variable: DeltaOut

b. Predictors: (Constant), RDesChar, RAdmnMotv, Rrisk, Rbenefit 
Coefficients $^{\mathrm{a}}$

\begin{tabular}{|c|c|c|c|c|c|c|c|c|}
\hline \multirow{2}{*}{\multicolumn{2}{|c|}{ Model }} & \multicolumn{2}{|c|}{$\begin{array}{l}\text { Unstandardized } \\
\text { Coefficients }\end{array}$} & \multirow{2}{*}{$\begin{array}{c}\text { Standardized } \\
\text { Coefficients } \\
\text { Beta }\end{array}$} & \multirow[b]{2}{*}{$\mathrm{t}$} & \multirow[b]{2}{*}{ Sig. } & \multicolumn{2}{|c|}{$\begin{array}{l}95.0 \% \text { Confidence } \\
\text { Interval for B }\end{array}$} \\
\hline & & B & Std. Error & & & & $\begin{array}{l}\text { Lower } \\
\text { Bound }\end{array}$ & $\begin{array}{l}\text { Upper } \\
\text { Bound }\end{array}$ \\
\hline \multirow[t]{5}{*}{1} & (Constant) & -2.957 & 3.075 & & -.962 & .338 & -9.035 & 3.121 \\
\hline & Rbenefit & 2.511 & 1.146 & .372 & 2.190 & .030 & .245 & 4.777 \\
\hline & Rrisk & -1.807 & .878 & -.302 & -2.058 & .041 & -3.542 & -.071 \\
\hline & RAdmnMotv & -.014 & .876 & -.002 & -.016 & .987 & -1.746 & 1.717 \\
\hline & RDesChar & -.286 & .877 & -.042 & -.327 & .744 & -2.020 & 1.447 \\
\hline
\end{tabular}

a. Dependent Variable: DeltaOut

\section{Second Step-wise Regression Results}

A second step-wise regression was conducted without the two constructs, Administrative Motivation for the Offshoring (RAdminMotv) and Desired Characteristics of Offshoring (RDesChar), that were shown to have non-significant influence on the expected growth in offshoring. Only the two independent constructs, Rbenefits and Rrisks, were entered in this step-wise regression on DeltaOut to test hypotheses $\mathrm{H} 1$ and $\mathrm{H} 2$. Table 3 show the results of the regression analysis.

The analysis indicates that both Benefits of Offshoring (Rbenefit) $[\mathrm{b}=2.379, \mathrm{p}=0.012]$, and Risks of Offshoring (Rrisk) $[\mathrm{b}=-1.899, \mathrm{p}=0.023]$, play significant roles in influencing offshoring decisions. As expected, perceived benefits (Rbenefit) has a positive influence on Expected Growth in Offshoring (DeltaOut), while perceived risks (Rrisk) has a negative influence on Expected Growth in Offshoring (DeltaOut).

Since the absolute value of the coefficient $\beta$ of the construct 'Benefits of Offshoring' (Rbenefit) at 2.379 is higher than the absolute value of the coefficient $\beta$ of the construct 'Risks of Offshoring' (Rrisk) at 1,899, it can be concluded that hypothesis H1 ("Expected Growth in offshoring is more influenced by perceived benefits than by perceived risks") is supported while hypothesis H2 hypothesizing that perceived risks will have a greater influence on offshoring decision is not supported. The perceived benefits of offshoring triumph over the perceived risks of offshoring.

In summary, of the four hypotheses, only one was supported (H1) and three were not supported (H2, $\mathrm{H} 3$ and H4). The Benefits of Offshoring positively influence the growth in IT offshoring while Risks of Offshoring negatively influence the said growth, but the former is a stronger influence on expected growth in offshoring than the latter. 
TABLE 3

SECOND STEP-WISE REGRESSION ANALYSIS

\begin{tabular}{|l|r|r|r|r|r|}
\hline \multicolumn{7}{|c|}{ Model Summary $^{\mathbf{b}}$} \\
\hline 1 & Rodel & R Square & $\begin{array}{c}\text { Adjusted R } \\
\text { Square }\end{array}$ & $\begin{array}{c}\text { Std. Error of the } \\
\text { Estimate }\end{array}$ & Durbin-Watson \\
\hline & $.210^{\mathrm{a}}$ & .044 & .031 & 8.616 & 2.056 \\
\hline
\end{tabular}

a. Predictors: (Constant), Rrisk, Rbenefit

b. Dependent Variable: DeltaOut

ANOVA $^{\mathrm{a}}$

\begin{tabular}{|ll|r|r|r|r|r|}
\hline Model & Sum of Squares & df & Mean Square & F & Sig. \\
\hline 1 & Regression & 496.608 & 2 & 248.304 & 3.345 & $.038^{\mathrm{b}}$ \\
& Residual & 10764.825 & 145 & 74.240 & & \\
Total & 11261.432 & 147 & & & \\
\hline
\end{tabular}

a. Dependent Variable: DeltaOut

b. Predictors: (Constant), Rrisk, Rbenefit

\begin{tabular}{|c|c|c|c|c|c|c|c|c|}
\hline \multicolumn{9}{|c|}{ Coefficients $^{\mathrm{a}}$} \\
\hline & & \multicolumn{2}{|c|}{$\begin{array}{c}\text { Unstandardized } \\
\text { Coefficients }\end{array}$} & \multirow{2}{*}{$\begin{array}{c}\text { Standardized } \\
\text { Coefficients } \\
\text { Beta }\end{array}$} & \multirow[b]{2}{*}{$\mathrm{t}$} & \multirow[b]{2}{*}{ Sig. } & \multicolumn{2}{|c|}{$\begin{array}{c}95.0 \% \\
\text { Confidence } \\
\text { Interval for B }\end{array}$} \\
\hline Model & & B & Std. Error & & & & $\begin{array}{l}\text { Lower } \\
\text { Bound }\end{array}$ & $\begin{array}{l}\text { Upper } \\
\text { Bound }\end{array}$ \\
\hline \multirow[t]{3}{*}{1} & (Constant) & -3.374 & 2.800 & & -1.205 & .230 & -8.908 & 2.161 \\
\hline & Rbenefit & 2.379 & .931 & .352 & 2.555 & .012 & .539 & 4.218 \\
\hline & Rrisk & -1.899 & .825 & -.317 & -2.300 & .023 & -3.530 & -.267 \\
\hline
\end{tabular}

a. Dependent Variable: DeltaOut

\section{LIMITATIONS OF THE STUDY}

Although this research makes many contributions, it is not without limitations. First, some bias may exist in the list of variables related to IT issues. A review of literature was conducted and perspectives from IS managers and scholars were incorporate into this investigation. However, additional variables could have been used.

Several possible reasons could contribute to items cross-loaded on more than one factor. First, an inclusion of an unidentified factor is possible. Second, the absence of a factor could also yield this result. Finally, the factors could be highly intercorrelated. All of these influences could result in the factors loading cleaner with a refined questionnaire. Furthermore, an instrument may need to be deployed several times before its construct validity can be established.

It should be noted the sample size of 148 respondents is moderate. The sample was divided approximately equally between the manufacturing and service sectors. The manufacturing segment included automobile, computer hardware, pharmaceutical, telecommunication (hardware and other). The service segment included banking, retail, hotels, computer software, construction, government, healthcare, insurance, technology, transportation, utilities, and other. The respondents were from the following departments: information systems, administration, accounting/finance, and production. An 
equal representation of each department was not present. In addition, other types of organizations, such as railways, chemicals, and airlines (operations and manufacturing) were not included in the sample. Therefore, any determinations based on the study could be limited to the list of companies in the directory. Accordingly, all interpretations of the study should consider the limits of variables and categories related to the sample.

\section{SUGGESTIONS FOR FURTHER RESEARCH}

The results of the study suggest future research would benefit from the creation of several conceptual models. Additional future research opportunities include an extension of this study to include the following factors: organizational maturity, IS sophistication, and other variables. Additionally, future research could include a longitudinal study and an examination of non-linear relationships.

Furthermore, future research would benefit from a refined survey instrument. Even though the existing survey added to the understanding of this exploratory topic, a revised survey could limit the number of cross-loaded factors. Given this research's focus on only two sectors (manufacturing and service), the generalizability is limited. Therefore, future research could benefit from a broader sample and a greater number of variables. Adding in industries such as airlines, railways, and chemicals could result in a more generalized model.

Along with the previously mentioned future research opportunities, a comparison among U.S. organizations and their counterparts in other countries would offer additional insights and could open avenues for collaboration.

\section{IMPLICATIONS FOR PRACTICE}

This research verifies that offshoring is a business strategy American organization will be utilizing for IT activities in the future. IT managers verified they will invest approximately the same percentage of their current (2016) IT budget into IT offshoring in the next five years (through 2021). IT managers indicated support for offshoring. However, they are also looking for additional options (such as cloud computing and application service providers) to benefit them.

The approximately equivalent IT budget in 2016 (and 5 years from 2016) will necessitate a comparable number of in-house IT professionals for the development of proprietary software, maintenance of IT applications, and advancement of infrastructure. In instances where 19 percent of IT budget is allotted toward IT offshoring, proportionally fewer IT professionals will need to be proficient in business processes. In these cases, readily supported IT applications can be carried out effectively in an offshore environment. Moreover, IT professionals are also needed for training to End-users. Working off the same hypothetical IT budget, the remaining 81 percent allocated to IT would be used for in-house IT departments, application service providers, and/or cloud computing vendors. If a majority of IT activity is completed in-house, a significant number of in-house IT professionals would be needed to support the organization. In turn, as IT functions shift to other domestic external sources (application service providers or cloud computing vendors) the need for in-house IT professionals would decline. In terms of business system planning, senior level IT professionals will still be needed to design IT strategy and guide the organization on ever-evolving IT architecture.

As the business world progresses toward natural language processing, IT applications will simplify. This shift is expected to decrease the number of IT professionals needed to support an organization. Likewise, the growth in End User Computing (EUC) will reduce the need for IT professionals in operations and software application maintenance. Generally, End-users will be able to develop smaller, one-time applications by themselves. Moreover, End-users will work alongside in-house IT professionals to provide input on the selection and acquisition of application software.

The IT curriculum in education institutions will need to be modified to accommodate the current and future trends in IT offshoring. In particular, the curriculum should adjust to instruct students equally on the development and implementation of IT resources. 
With more IT departments drawing on outsourcers (application service providers and/or cloud computing vendors) the need for IT vendor development and engagement will become a top priority for the organization (as it is already in the manufacturing and other service branches of most businesses). Additionally, as technology is developed at an ever-increasing speed, consultants will be needed to advise in-house IT professionals on IT strategy and architecture.

Based on the aforementioned discussion, the reliance of American companies on offshoring in the IT sector will continue to significantly influence organizations and educational institutions. In response, government policies and tax structure will adjust to this change in business practice. Finally, the trend toward IT offshoring will arguably begin a new chapter in the management of IT resources. Thus, leading to new research opportunities in the discipline.

\section{CONCLUDING REMARKS}

The main objective of this study was to arrive at a better understanding of the current and future trends in the usage of IT offshoring and its implications for organizations in the United States. The perceived usage of approximately same percentage (in 2016 and 5 years from 2016) of allocation of IT budget in this option leads us to believe that IT is not as much a source of competitive advantage as it was in the past to the corporations.

Regression analysis leads us to the conclusion that companies engage in offshoring driven primarily by the bandwagon effects. The other potential perceived risks and motivations seem to be neutralized by the managers' desire to "not miss the boat' when other companies are engaged in offshoring

\section{REFERENCES}

Anderson, S. W., \& Sedatole, K.L. (2003). Management accounting for the extended enterprise: Performance management for strategic alliances and networked partners. In Management Accounting in the Digital Economy, edited by A. Bhimani, 481-506. New York, NY: Oxford University Press.

Antonucci, Y.L., \& Tucker, J. (2013). IT outsourcing: Current trends, benefits, and risks. Information Strategy: The Executives Journal, 16-26.

Apte, U. M., \& Mason, R.O. (1995). Global disaggregation of information-intensive services. Management Science, 41(7), 1250-1263.

Aron, R., \& Singh, J. V. (2005). Getting offshoring right. Harvard Business Review, 83, 135-143.

Baden-Fuller, C., Targett, D., \& Hunt, B. (2000). Offshoring to outmaneuver: offshoring re-defines competitive strategy and structure. European Management Journal, 18(3), 285-295.

Bahli, B., \& Rivard, S. (2013). Cost escalation in information technology outsourcing: A moderated mediation study. Decision Support Systems, 56, 37 - 47.

Bakhtiari, S. (2015). Productivity, outsourcing, and exit: The case of Australian manufacturing. Small Business Economics, 44, 425-447.

Bardi, E. J., \& Tracey, M. (1991). Transportation outsourcing: A survey of U.S. practices. International Journal of Physical Distribution and Logistics Management, 21(3), 15-21.

Barney, J. (1991). Firm resources and sustained competitive advantage. Journal of Management, 17(1), 99-120.

Barney, J. (2012). Purchasing, supply chain management and sustained competitive advantage: The relevance of resource-based theory. Journal of Supply Chain Management, 48(2), 3-6.

Betancourt, P., Mooney, J.G., \& Ross, J.W. (2015). Digital innovation at Toyota Motor North America: Revamping the role of IT. Working Paper 403. MIT Sloan School of Management Center for Information Systems Research, Cambridge, Massachusetts, October, http:/cisr.mit.edu.

Bhagwatwar, A., Hackey, R., \& Desouza, K.C. (2011). Considerations for information systems 'backsourcing': A framework for knowledge re-integration. Information Systems Management, 28(2), 165-173. 
Bianchi, M., Di Benedetto, A., Franzò, S., \& Frattini, F. (2017). Selecting early adopters to foster the diffusion of innovations in industrial markets: Evidence from a multiple case study. European Journal of Innovation Management, 20(4), 620-644.

Blankenship, A. B., Breen, G. E., \& Dutka, A. F. (1998). State of the art marketing research. Chicago, IL: NTC Business Books.

Blinder, A. (2006). Offshoring: The next industrial revolution? Foreign Affairs, 85, 113-128.

Boston Consulting Group. (2013). Majority of large manufacturers are now planning or considering reshoring from China to the US. Press releases. Retrieved from http://www.bcg.com/media/PressReleaseDetails.asp?id=tcm:12-144944

Business News Daily. (2010). Offshoring and temps make for grumbling workers. Business News Daily, Retrieved from http://www.businessnewsdaily.com/51-outsourcing-and-temps-make-forgrumbling-workers.html

Bustinza, O.F., Arias-Aranda, D., \& Gutierrez-Gutierrez, I. (2010). Offshoring competitive capabilities and performance: An empirical study in service firms. International Journal of Production Economics, 126(2), 276-288.

Carmel, E. (2003). The new software exporting nations: Success factors. The Electronic Journal of Information Systems in Developing Countries, 13(4), 1-12.

Carmel, E. (2006). Building your information systems from the other side of the world: How Infosys manages time zone differences. MIS Quarterly Executive, 5(1), 43-53.

Choi, J-Y., \& Beladi, H. (2014). Internal and external gains from international outsourcing. The Journal of International Trade \& Economic Development, 23(2), 299-314.

Choudhury, V., \& Sabherwal, R. (2003). Portfolios of control in outsourced software development projects. Information Systems Research, 14(3), 291 - 314.

Computer Economics. (2017a). IT spending \& staffing benchmark, 2017/2018. Computer Economics.

Computer Economics. (2017b). IT offshoring statistics, 2016/2017. Computer Economics.

Contractor, F. J., Kumar, V., Kundu, S.K., \& Pedersen, T. (2010). Reconceptualizing the firm in a world of offshoring and offshoring: The organizational and geographical relocation of high-value company functions. Journal of Management Studies, 47(8), 1417-1433.

Dabhilkar, M., Bengtsson, L., von Haartman, R., \& Ahlstrom, P. (2009). Supplier selection or collaboration? Determining factors of performance improvement when offshoring manufacturing. Journal of Purchasing and Supply Management, 15(3), 143-153.

Deutsch, Y., Keil, T., \& Laamanen, T. (2011). A dual agency views of board compensation: The joint effects of outside director and CEO stock options on firm risk. Strategic Management Journal, $32(2), 212-227$.

Dhar, S. (2012). From offshoring to cloud computing: Evolution of IT services. Management Research Review, 35(8), 664-675.

Di Gregorio, D., Musteen, M., \& Thomas, D.E. (2009). Offshore offshoring as a source of international competitiveness for SMEs. Journal of International Business Studies, 40(6), 969-988.

Dillman, D.A. (1978). Mail and Telephone Surveys: The Total Design Method. New York: Wiley Intersciences.

Dillman, D.A. (2000). Mail and Internet Surveys: The Tailored Design Method, 2nd Edition. New York: John Wiley Co.

Dolgui, A., \& Proth, J-M. (2013). Outsourcing: Definition and analysis. International Journal of Production Research, 51(23-24), 6769-6777.

Earl, M.J. (1996). The risks of offshoring IT. MIT Sloan Management Review, 37(3), 26-32.

Farrell, D. (2005). Offshoring: Value creation through economic change. Journal of Management Studies, 42, 675-683.

Fitoussi, D., \& Gurbaxani, V. (2012). IT offshoring contracts and performance measurement. Information Systems Research, 23(1), 129-143.

Gaudenzi, B., \& Borghesi, A. (2006). Managing risks in the supply chain using the AHP method. The International Journal of Logistics Management, 17(1), 114-136. 
Gereffi, G., \& Lee, J. (2012). Why the world suddenly cares about global supply chains. Journal of Supply Chain Management, 48(3), 24-32.

Gomez-Mejia, L. R., \& Palich, L. E. (1997). Cultural diversity and the performance of multinational firms. Journal of International Business Studies, 28(2), 309-335.

Goolsby, K. (2004). What causes offshoring failure? Dallas, TX: The offshoring center. Retrieved from http://www.outsourcing-center.com/2004-08-what-causes-outsourcing-failure-article-37826.html

Gottfredson, M., Puryear, R., \& Phillips, S. (2005). Strategic sourcing from periphery to the core. Harvard Business Review, 83(2), 132-139.

Han, K., \& Mithas, S (2013). Information technology offshoring and non-IT operating costs: An empirical investigation. MIS Quarterly, 37(1), 315-331.

Hess, M. (2018). The bandwagon effects in networks: a literature review. Retrieved from https://www.alexandria.unisg.ch/publications/254259

Hilletofth, P., \& Hilmola, O.P. (2010). Role of logistics offshoring on supply chain strategy and management: Survey findings from Northern Europe. Strategic Outsourcing: An International Journal, 3(1), 46-61.

Hilletofth, P., \& Jäger, K. (2011). Role of logistics service providers in the implementation of a differentiated supply chain. International Journal of Shipping and Transport Logistics, 3(2), 151167.

Holcomb, T.R., \& Hitt, M.A. (2007). Toward a model of strategic outsourcing. Journal of Operations Management, 25(2), 464-481.

Holweg, M., Reichhart, A., \& Hong, E. (2011). On risk and cost in global sourcing. International Journal of Production Economics, 131(1), 333-341.

Horgos, D. (2009). Labor market effect of international outsourcing: How measurement matters. International Review of Economics and Finance, 18(4), 611-623.

Huber, T.L., Fisher, T.A., Kirsch, L., \& Dibbern, J. (2014). Explaining emergence and consequences of specific formal controls in IS outsourcing: A process-view. Proceedings of the 47th Hawaii International Conference in Information Systems, 6-9 January, Waikoloa, HI.

International Association of offshoring Professionals (IAOP). (2010). 2011 Trends forecast shows industry redefined: Greater political backing for offshoring among top 10 predictions. Retrieved from http://www.finance.yahoo.com/news/International-Association-of-iw-3819268013.html

International Data Corporation (IDC). (2013). Worldwide and U.S. business process offshoring services 2013-2017 forecast: Time for customers to reap the emerging benefits of transformative and agile BPO services. Retrieved from http://www.idc.com/getdoc.jsp?containerId=240860

Iyengar, H. (2011). Global BPO market to reach revenues of $\$ 93.4$ billion. Retrieved from http://itvoir.com/portal/resources/Market-Watch/Global-BPO-market-to-touch-revenues-of-93-4billion.asp

Jain, D.M., \& Khurana, R. (2013). Need for sustainable global business model in software offshoring the Indian perspective. Business Process Management Journal, 19(1), 54-69.

Jain, D.M., \& Khurana, R. (2015). Impact of pricing and offshoring models on Indian information technology service outsourcing. Benchmarking: An International Journal, 22(4), 610-623.

Kahneman, D., \& Tversky, A. (1984). Choices, Values and frames. American Psychologist, 39(4), 341350 .

Kakabadse, A., \& Kakabadse, N. (2000). Sourcing: New face to economies of scale and the emergence of new organizational forms. Knowledge and Process Management, 7(2), 107-108.

Kakabadse, A., \& Kakabadse, N. (2002). Trends in outsourcing: Contrasting USA and Europe. European Management Journal, 20(2), 189-198.

Kang, M., Wu, X., Hong, P., \& Park, Y. (2012). Aligning organizational control practices with competitive out-sourcing performance. Journal of Business Research, 65(8), 1195-1201.

Kern, T., \& Willcocks, L. P. (2002). Exploring relationship in information technology outsourcing: the interaction approach. European Journal of Information Systems, 11(1), 3-19. 
Khan, N., Currie, W., Weerakkody, V., \& Desai, B. (2003). Evaluating offshore IT offshoring in India: Supplier and customer scenarios. Proceedings of the 36th Hawaii International Conference on Systems Sciences (HICSS'03), 8(8), IEEE Computer Society, Washington, DC, USA.

Kim, Y.J., Lee, J.M., Koo, Ch., \& Nam, K. (2013). The role of governance effectiveness in explaining IT offshoring performance. International Journal of Information Management, 33(5), 850-860.

Kriger, A.B., Ivin, V.V., Glotova, E.A., Kiykova, E.V., \& Lavrushina, E.G. (2016). Information technology outsourcing trends at higher education of the Russian Far Eastern in the context of global tendencies in information technology outsourcing. Journal of Internet Banking and Commerce, 21(2), 1-13.

Kremic, T., Tukel, O.I., \& Rom, W.O. (2006). offshoring decision support: A survey of benefits, risks, and decision factors. Supply Chain Management: An International Journal, 11(6), 467-482.

Lacity, M. C., Khan, S. A., \& Willcocks, L. P. (2009). A review of the IT offshoring literature: Insights for practice. Journal of Strategic Information Systems, 18(3), 130-146. doi: 10.1016/j.jsis.2009.06.002.

Lacity, M.C., Willcocks, L.P., \& Feeny, D.F. (1995). IT Outsourcing: Maximize flexibility and control. Harvard Business Review, 73(3), 84-93.

Lacity, M. C., \& Willcocks, L. P. (2012). Advanced offshoring practice: Rethinking ITO, BPO and cloud services. Basingstoke, England: Palgrave Macmillan.

Lee, J.-N., \& Kim, Y.-G. (1999). Effect of partnership quality on IS offshoring success: Conceptual framework and empirical validation. Journal of Management Information Systems, 15(4), 29-61.

Lei, D., \& Hitt, M. A. (1995). Strategic restructuring and outsourcing: The effect of mergers and acquisitions and LBOs on building firm skills and capabilities. Journal of Management, 21(5), 835-859.

Letica, M. (2016). The effect of offshoring activities selection on the benefits of outsourcing. Management, 21(2), 77-97.

Levina, N., \& Su, N. (2008). Global multisourcing strategy: The emergence of supplier portfolio in service offshoring. Decision Sciences, 39(3), 541-570.

Levy, D.L. (2005). Offshoring in the new global political economy. Journal of Management Studies, 42(3), 685-693.

Lewin, A.Y., \& Peeters, C. (2006). Offshoring work: Business hype or the onset of fundamental transformation? Long Range Planning, 39(3), 221-239.

Li, S., \& Scullion, H. (2006). Bridging the distance: Managing cross-border knowledge holders. Asia Pacific Journal of Management, 23(1), 71-92.

Li, Y., Liu, Y., Li, M., \& Wu, H. (2008). Transformational offshore outsourcing: Empirical evidence from alliance in China. Journal of Operations Management, 26(2), 257-274.

Linder, J.C. (2004a). Transformational outsourcing. Supply Chain Management Review, 8(4), 54-61.

Luftman, J., Zadeh, H.S., Derksen, B., Santana, M., Rigoni, E., and Huang, Z.D. (2013). Key information technology and management issues 2012-2013: An international study. Journal of Information Technology, 354-366.

Manning, S., Massini, S., \& Lewin, A. Y. (2008). A dynamic perspective on next-generation offshoring: The global sourcing of science and engineering talent. Academy of Management Perspectives, 22(3), 35-54.

Marchewka, J.T., \& Oruganti, S. (2013). A combined model of IT offshoring partnership and success. Communications of the IIMA, 13(2), 69-85.

Massini, S., Perm-Ajchariyawong, N., \& Lewin, A. Y. (2010). Role of corporate-wide offshoring strategy on offshoring drivers, risks and performance. Industry and Innovation, 17, 337-371.

McNally, R.C., Akdeniz, M.B., \& Calantone, R.J. (2011). New product development processes and new product profitability: Exploring the mediating role of speed to market and product quality. Journal of Product Innovation Management, 28, 63-77.

Nassimbeni, G. (2006). International sourcing: empirical evidence from a sample of Italian firms. International Journal of Production Economics, 103(2), 694-706. 
Natovich, J. (2003). Vendor related risks in IT development: A chronology of an outsourced project failure. Technology Analysis \& Strategic Management, 15(4), 409 - 419.

Ndubisi, N.O., \& Nataraajan, R. (2015). Internationalization and international service management. Journal of Service Management.

Nieto, M. J., \& Rodriguez, A. (2011). Offshoring of R\&D: Looking abroad to improve innovation performance. Journal of International Business Studies, 42, 345-361.

Olson, D.L. and Wu, D. (2011). Risk management models for supply chain: A scenario analysis of offshoring to China. Supply Chain Management: An International Journal, 16(6), 401-408.

Oshri, L., Kotlarsky, J., \& Willcocks, L. (2007). Managing dispersed expertise in IT offshore outsourcing: Lessons from Tata Consultancy Services. MIS Quarterly Executive, 6(2), 53-65.

Overby, S. (2005). Backsourcing pain. CIO Magazine, 18(22), 64-72.

Peng, M. W., \& Delios, A. (2006). What determines the scope of the firm over time and around the world? An Asia Pacific perspective. Asia Pacific Journal of Management, 23, 385-405.

Pfannenstein, L.L., \& Tsai, R.J. (2004). Offshore outsourcing: Current and future effect on American IT industry. Information Systems Management, 21(4), 72-80.

Platts, K.W., \& Song, N. (2010). Overseas sourcing decisions - the total cost of sourcing from China. Supply Chain Management: An International Journal, 15(4), 320-331.

Prikladnicki, R., \& Audy, J.L.N. (2012). Managing global software engineering: A comparative analysis of offshore offshoring and internal offshoring of software development. Information Systems Management, 29, 216-232.

Qi, C., \& Chau, P. Y. (2012). Relationship, contract and IT offshoring success: Evidence from two descriptive case studies. Decision Support Systems, 53(4), 859 - 869.

Quinn, J. B. (2000). Offshoring innovation: The new engine of growth. Sloan Management Review, 41(4), $13-28$.

Ranganathan, C., \& Balaji, S. (2007). Critical capabilities for offshore offshoring of information systems. MIS Quarterly Executive, 6(3), 147-164.

Rao, S., \& Goldsby, T.J. (2009). Supply chain risks: A review of typology. The International Journal of Logistics Management, 20(1), 97-123.

Reynolds, P. (2012). Top 5 things to know about record-setting offshoring activity in 2011. Retrieved from http://www.isg-one.com/web/Top5/archive/120314.asp

Rodriguez, A., \& Nieto, M. J. (2016). Does R \& D offshoring lead to SME growth? Different governance modes and the mediating role of innovation. Strategic Management Journal, 37, 1734-1753.

Rogers, E. M. (2010). Diffusion of innovations. 4th Edition, Simon and Schuster.

Rottman, J.W., \& Lacity, M.C. (2004). Twenty practices for offshore sourcing. MIS Quarterly Executive, $3(3), 117-130$.

Schwarz, C. (2014). Toward an understanding of the nature and conceptualization of offshoring success. Information \& Management, 51(1), 152-164.

Seddon, P.B., Cullen, S., \& Willcocks, P. (2007). Does Domberger's theory of the contracting organization' explain why organizations outsource IT and the level of satisfaction achieved? European Journal of Information Systems, 16, 234-253.

Solli-Sæther, H., \& Gottschalk, P. (2015). Stages-of-growth in outsourcing, offshoring and backsourcing: Back to the future? The Journal of Computer Information Systems, 55(2), 88-94.

Sonnenberg, F. K. (1992). Partnering: Entering the age of cooperation. Journal of Business Strategy, 13(3), 49-52.

Stratman, J. K. (2008). Facilitating offshoring with enterprise technologies: Reducing operational friction in the governance and production of services. Journal of Operations Management, 26(2), 275287.

Su, N, Levina, N., \& Ross, JW. (2016). The long-tail strategy for IT outsourcing. MIT Sloan Management Review, 57(2), Winter, 80-89.

Tadelis, S. (2007). The innovative organization: Creating value through outsourcing. California Management Review, 50, 261-277.

26 Journal of Management Policy and Practice Vol. 20(3) 2019 
Teece, D. J. (2007). Explicating dynamic capabilities: The nature and microfoundations of (sustainable) enterprise performance. Strategic Management Journal, 28, 1319-1350.

Tsao, S.-M., \& Chen, G.-Z. (2012). The impact of internationalization on performance and innovation: The moderating effects of ownership concentration. Asia Pacific Journal of Management, 29(3), 617-642.

Tversky, A., \& Kahneman, D. (1992). Advances in prospect theory: Cumulative representation of uncertainty. Journal of Risk and Uncertainty, 5(4), 297-323.

Veltri, N. F., Saunders, C. S., \& Kavan, C. B. (2008). Information systems backsourcing: correcting problems and responding to opportunities. California Management Review, 51(1), 50-76.

Venkatraman, N. (2004). Offshoring without guilt. Sloan Management Review, 45(3), 14-30.

Westner, M. K., \& Strahringer, S. (2010a). The current state of IS offshoring in Germany: Project characteristics and success patterns. Journal of Information Technology Management, 21(1), 4970.

Whitten, D., \& Leidner, D. (2006). Bringing IT back: an analysis of the decision to backsource or switch vendors Decision Sciences, 37(4), 605-621.

Wüllenweber, K., \& Weitzel, T. (2007). An empirical exploration of how process standardization reduces offshoring risk. Proceedings of 40th Hawaii International Conference on System Sciences (HICSS40), Hawaii, USA.

Yap, C-S., Lim, Y-M., \& Lee, Teck-Heang (2013). Explaining IT offshoring satisfaction using Domberger's theory: An SME perspective. Gadjah Mada International Journal of Business, 15(1), 45-60.

Zatolyuk, S., \& Allgood, B. (2004). Evaluating a country for offshore outsourcing: Software development providers in the Ukraine. Information Systems Management, 21(3), 28-33.

Zeng, A. Z., \& Rossetti, C. (2003). Developing a framework for evaluating the logistics costs in global sourcing processes. International Journal of Physical Distribution and Logistics Management, 33(9), 785-803.

Zhu, X. (2016). Managing the risk of outsourcing: Time, quality and correlated costs. Transportation Research Part E, 90, 121-133.

Zhu, Z., Hsu, K., \& Lillie, J. (2001). Outsourcing-A strategic move: The process and the ingredients for success. Management Decision, 39(5), 373-378. doi:10.1108/EUM0000000005473. 